Osmanlı Medeniyeti Araştırmaları Dergisi
Journal of Ottoman Civilization Studies

DOI: 10.21021/osmed.729639

Makale Türü: Araştırma Makalesi

Article Types: Research Article

Geliş Tarihi \& Received: 30.04 .2020

Kabul Tarihi \& Accepted: 15.07.2020

OSMED, 2020, 6(11): 120-140

\title{
Prenses Gisela ve Oğullarının İstanbul Seyahati (11 Nisan-4 Mayıs 1908)
}

Princess Gisela and Her Sons Trip to Istanbul (11 April-4 May 1908)

\section{Senem GÖNENÇ*}

\section{$\ddot{O} \mathbf{z}$}

Bu çalışmada, Avusturya-Macaristan İmparatoru Franz Joseph'in kızı ve Bavyera Prensi Leopold'ün eşi Prenses Gisela'nın 1908 baharında İstanbul'a gerçekleştirdiği seyahat ele alınmaktadır. Doküman incelemesine dayanan çalışmanın verileri Osmanlı arşivinde yer alan belgeler ile Osmanlı ve Avusturya gazetelerinden elde edilmiştir. Çalışma, Prenses'in oğullarıyla birlikte İstanbul'un görülmeye değer mekânlarına yaptığı gezileri gün yüzüne çıkarırken dönemin teşrifat uygulamalarına da 1şık tutmaktadır. Sultan II. Abdülhamid'in gösterdiği misafirperverlik ve İmparator Franz Joseph ile yaptığı yazışmalar ise genellikle çatışma ve rekabet ile anılan Osmanlı ve Habsburg ilişkilerinin dostane boyutuna dikkat çekmesi bakımından önem arz etmektedir.

Anahtar kelimeler: II. Abdülhamid, Avusturya-Macaristan, Franz Joseph, İstanbul, Prenses Gisela

\begin{abstract}
In this study, the trip of Princess Gisela, the daughter of Austro-Hungarian Emperor Franz Joseph and the wife of Bavarian Prince Leopold, to Istanbul in the spring 1908 is handled. The information of the study based on the document analysis was obtained from the documents in the Ottoman archive and the news in the Ottoman and Austrian press. The study, sheds light on the ceremony of this period and places of Istanbul which worth seeing during the trips of the Princess with her sons. The hospitality of Sultan Abdul Hamid II and his correspondence with Emperor Franz Joseph are important in terms of drawing attention to the friendly dimension of the Ottoman and Habsburg relations, which are often referred to by conflict and competition.
\end{abstract}

Keywords: Abdul Hamid II, Austria-Hungary, Franz Joseph I, Istanbul, Princess Gisela

* (Dr.) İstanbul Üniversitesi-Cerrahpaşa, senemgonenc@hotmail.com; ORCID:orcid.org/0000-0002-3267-7580

Kaynak Gösterme: Gönenç, S. "Prenses Gisela ve Oğullarının İstanbul Seyahati (11 Nisan-4 Mayıs 1908)". Osmanlı Medeniyeti Araştırmaları Dergisi, 6 (2020): 120-140. 


\section{Giriş}

1908 yılı daha ilk aylarından itibaren Osmanlı ve Avusturya-Macaristan imparatorlukları arasındaki ilişkiler açısından önemli siyasi gelişmelerin yaşandığı bir yıl olmuştur. Nitekim 27 Ocak 1908'de Avusturya-Macaristan İmparatorluğu'nun Dışişleri Bakanı Baron Aehrenthal (1854-1912), Macaristan Delegasyonu'nda oldukça dikkat çeken bir beyanatta bulunmuştur. Aehrenthal bu beyanatında Avusturya demir yollarını Rumeli demir yollarına birleştirmek amacıyla Saraybosna'dan Mitroviçe'ye uzanan bir demir yolu projesinden bahsetmiştir. ${ }^{1}$

Berlin Antlaşması'nın (1878) 25. maddesine göre Avusturya-Macaristan'a Sancak'ta askerî kuvvet bulundurma, ticari ve askerî yollar inşa etme hakkı verilmişti. Bu yolların inşasına ait müzakereler de Avusturya ile Osmanlı Devleti'ne bırakılmıştı. Bu açıdan bakıldığında Aehrenthal'in projesine itiraz edilemezdi. Ancak bu projenin Avusturya'nın Rusya ile yaptığı anlaşmayı ihlal ettiği iddia edilebilirdi. Zira 29 Nisan 1897'de Avusturya ve Rusya devletleri tarafindan Balkan hükûmetlerine tebliğ edilen notada iki devletin statükoyu korumaya karar verdikleri beyan edilmişti. Osmanlı memleketlerinden bir demir yolu imtiyazı alınması ise statükoyu Avusturya lehine bozmuş olacaktı. Bu durum sadece Yeni Pazar' da değil bütün Kosova vilayeti dâhilinde Avusturya nüfuzunun genişlemesine sebep olacağından başta Rusya ve İngiltere olmak üzere diğer büyük devletler ve Balkan hükûmetlerinde büyük bir yank1 uyandırmış ve endişe ile karşılanmıştır. ${ }^{2}$

4 Şubat 1908 tarihinde Sultan II. Abdülhamid'in söz konusu projeye yönelik lütufkâr bir irade ihsan etmesi bir bakıma Avrupa devletler konseyini parçalamaya ve Makedonya'da Mürzsteg güçlerinin örgütledikleri adli reformlar tehdidinden kurtarmaya yönelik bir hamle olurken iki imparatorluk arasındaki ilişkiler tam da bu aylarda yakınlaşmaya başlamıştır. ${ }^{3} \mathrm{Bu}$ siyasi gelişmelerin gölgesinde Prenses Gisela; oğlu ve yeğeni ile birlikte Nisan 1908'de Osmanlı İmparatorluğu'nun payitaht1 İstanbul'a bir seyahat gerçekleştirmiştir. ${ }^{4}$

Prenses Gisela, 12 Temmuz 1856'da Avusturya İmparatoru ve Macaristan Kralı Franz Joseph (18301916) ile İmparatoriçe Elisabeth'in (1837-1898) ikinci çocukları olarak Laxenburg'da dünyaya gelmiştir. 20 Nisan 1873'te kuzeni Bavyera Prensi Leopold (1846-1930) ile evlenmiş ve bu evlilikten dört çocukları olmuştur: İlk çocuğu Prenses Elisabeth Marie (1874-1957), 1893'te Kont Seefried ile evlenmiş ve kısmen Viyana'da, kısmen de Gresten yakınlarındaki bir kalede yaşamıştır. Aynı yıl, ikinci kızı Prenses Auguste (1875-1964) Budapeşte'de yaşayan Arşidük Joseph ile evlenmiştir. Prenses Gisela'nın üçüncü çocuğu Prens George (1880-1943), 1912'de Arşidüşes Isabella ile evlenmiştir. Ancak

\footnotetext{
${ }^{1}$ Her ne kadar bu proje gerçekleştirilememiş olsa da yol açtığı gelişmeler I. Dünya Savaşı'na giden yolda devletlerin bloklaşma sürecinde önemli bir rol oynamıştır. Bu proje ve akabinde vuku bulan gelişmeler için ayrıca bkz. Senem Gönenç, “Osmanlı-Avusturya Macaristan İmparatorluğu ilişkileri (1908-1914) ve Ders Kitaplarına Yansımaları" (doktora tezi, İstanbul Üniversitesi, 2019), 69-90.

2 Başbakanlık Osmanlı Arşivi (BOA), Yıldız Perakende Evrakı Tahrirat-ı Ecnebiye ve Mabeyn Mütercimliği (Y.PRK.TKM), 51/20, t.y., s. 2; Yıldız Esas Evrakı (Y.E.E), 83/10, 6 R 1326/8 Mayıs 1908.

${ }^{3}$ F. R. Bridge, "Habsburg Monarşisi ve Osmanlı Imparatorluğu, 1900-1918”, Osmanlı Imparatorluğu'nun Sonu ve Büyük Güçler, haz., Marian Kent (İstanbul: Alfa Yayınları, 2013), 66.

4 Prenses Gisela'nın babası Imparator Franz Joseph de 1869 'da İstanbul'a gelmiştir. Keza Prenses'in esrarengiz şekilde ölen kardeşi Arşidük Rudolf (1858-1889) 14-27 Nisan 1884 tarihleri arasında eşi ile birlikte İstanbul'a gelmiştir. Veliaht Arşidük, İstanbul'a 13 Haziran 1888'de bir kez daha gelmiştir (Yılmaz Öztuna, II. Abdülhamîd: Zamânı ve Şahsiyeti (İstanbul: Kubbealtı, 2008), 19, 219. Tercüman-ı Hakikat gazetesinde Prenses Gisela'nın İstanbul'a Padişah'a dostane ve içten duygularını arz etmek üzere geldiği ifade edilmektedir ("Prenses Gizela Hazretleri", Tercüman-ı Hakikat, nr: 9713, 15 Nisan 1908, s. 1).
} 
bu evliliği bir yıldan az sürmüştür. Prens Georg, Bavyera ordusunda I. Dünya Savaşı da dâhil olmak üzere önemli askerî görevlerde bulunduktan sonra Roma'da din görevlisi olarak hayatını kaybetmiştir. Prenses Gisela'nın en küçük çocuğu Prens Konrad (1883-1969) ise İmparatorluk Meclisi üyesi olarak görev yapmıştır. 1921'de Savonen-Genua Prensesi Bona Margerite ile evlenmiştir. Bavyera Prensesi Gisela, 27 Temmuz 1932'de uzun bir hastalıktan sonra Münih'te oldukça popüler bir figür olarak 76 yaşında yaşamını yitirmiştir. ${ }^{5}$ Prenses Gisela'nın ölümü ile İmparator Franz Joseph ve İmparatoriçe Elisabeth'in dört çocuğunun sonuncusu da hayatını kaybetmiştir. ${ }^{6}$

\section{Prenses Gisela ve Diğer Hanedan Üyelerinin İstanbul'a Geleceğinin Bildirilmesi}

14 Mart 1908 tarihinde, Prenses Gisela'nın büyük oğlu Prens Georg İtalya ve Doğu seyahatine başlamıştır. İlk olarak Roma'ya gitmiştir. ${ }^{7} 31$ Mart'ta Kont Wartenstein takma adıyla Baron Berfall ile birlikte Kudüs'e gitmiştir. ${ }^{8} 6$ Nisan akşamı Prenses Gisela ise küçük oğlu Prens Konrad ile birlikte Budapeşte'de ikamet eden kızı Arşidüşes Auguste'yi ziyaret etmek için Münih'ten Budapeşte'ye hareket etmiştir. ${ }^{9}$ Prenses Gisela ve oğlu Budapeşte' de Hotel Hungaria'da kalmışlardır. ${ }^{10}$ Prenses Gisela'nın İstanbul seyahatinde kendisine eşlik eden bir diğer isim olan Prens Heinrich ise Münih'ten Viyana'ya gelmiş ve imparatorluk ailesini ziyaret ettikten sonra 8 Nisan'da Şark Ekspres treniyle Viyana' dan Budapeşte'ye geçmiştir. ${ }^{11}$ Bu sırada Avusturya basınında Prenses Gisela'nın Budapeşte'den sonra İstanbul'a geleceğine, burada on gün kadar kalacağına ${ }^{12}$ ve o sırada Misır'da bulunan Prens Georg ile İstanbul'da buluşacaklarına ilişkin haberler yer almaya başlamıştır. ${ }^{13}$ Keza söz konusu seyahat ile ilgili olarak Sultan II. Abdülhamid'in de Prenses Gisela'nın Yıldız Sarayı'nda kalmasını teklif ettiği ve bu teklifinin Prenses Gisela tarafindan seyahatini gizli şekilde gerçekleştireceği gerekçesiyle teşekkürle kabul edilmediği ifade edilmiştir. ${ }^{14}$

Prenses Gisela'nın; oğlu Prens Konrad ve yeğeni Prens Heinrich ile birlikte 11 Nisan 1908 tarihinde İstanbul'a gelecekleri resmî olarak Berlin Sefareti aracılığıla Osmanlı Hariciye Nezareti'ne bildirilmiştir. Bu seyahat sırasında Prenses Gisela ile oğlunun Kontes ve Kont Wartemberg takma adlarını, Prens Heinrich'in de gerçek adını kullandığı ve kendilerine sınırdaki gümrük memurlarına gösterilmek üzere mürur tezkereleri verildiği belirtilmiştir. ${ }^{15}$ Ardından bu hususta Hariciye ve Dâhiliye

\footnotetext{
5 "Prenses Jizel Hazretleri", Tercüman-ı Hakikat, nr: 9710, 12 Nisan 1908, s. 2; "Amtlicher Teil”, Wiener Zeitung, nr: 97, 26 Nisan 1913, s. 1; “Prinzessin Gisela von Bayern”, Wiener Zeitung, nr: 174, 29 Temmuz 1932, s. 5.

6 "Prinzessin Gisela", Reichspost, nr: 210, 29 Temmuz 1932, s. 7.

7 "Von fremden Höfen", Sport\&Salon, nr: 12, 21 Mart 1908, s. 4; “Aus hofkreisen”, Wiener Salonblatt, nr: 14, 4 Nisan 1908, s. 5.

8 "Prinz Georg von Bayern", Das Vaterland (Abendblatt), nr: 182, 18 Nisan 1908, s. 2.

9 "Von fremden Höfen", Wiener Salonblatt, nr: 15, 11 Nisan 1908, s. 5.

10 "Hofnachrichten", Das Vaterland (Abendblatt), nr: 166, 9 Nisan 1908, s. 7; "Prinzessin Gisela von Bayern", Deutsches Volksblatt, nr: 6923, 9 Nisan 1908, s. 8.

11 "Vom Hofe, Neuigkeits-Welt Blatt, nr: 84, 10 Nisan 1908, s. 7.

12 "Orientreise der Prinzessin Gisela von Bayern", Die Zeit (Abendblatt), nr: 1993, 10 Nisan 1908, s. 3; "Türkei", Wiener Abendpost, nr: 86, 13 Nisan 1908, s. 3; "Prinzessin Gisela in Konstantinopel”, Die Zeit (Abendblatt), nr: 1996, 13 Nisan 1908, s. 4; “Prenses Jizel Gizela Hazretleri”, Tercüman-ı Hakikat, nr: 9712, 14 Nisan 1908 , s. 2.

13 "Von fremden Höfen", Wiener Salonblatt, nr: 15, 11 Nisan 1908, s. 5.

14 "Orientreise der Prinzessin Gisela von Bayern", Neues Wiener Journal, nr: 5199, 11 Nisan 1908, s. 5; "Hofnachrichten", Das Vaterland (Morgenblatt), nr: 169, 11 Nisan 1908, s. 6.

15 İrâde-Hariciye (I.HR), 412/2, 5 Nisan 1908, s. 1; "Prinzessin Gisela in Konstantinopel", Das Vaterland (Abendblatt), nr: 172, 13 Nisan 1908, s. 3; Gönenç, a.g.t., s. 314.
} 
Nezaretlerine, Rüsumat Emanetine ve Edirne vilayetine tebligat yapılmıştır. Bu makamlarca da lazım gelenlere derhâl gerekli tebligatın yapılması istenmiştir. ${ }^{16}$

\section{Prenses Gisela ve Diğer Hanedan Üyelerinin İstanbul Günleri}

Prenses Gisela, Mustafa Paşa'daki Türk sınırında Edirne valisi tarafından karşılandıktan sonra ${ }^{17} 11$ Nisan Cumartesi günü saat birde oğlu Prens Konrad, yeğeni Prens Heinrich ve mabeyincileri Baron Maks von Faliç ile birlikte Şark Sürat Katarı'yla İstanbul Sirkeci istasyonuna gelmiştir. Burada Prenses Gisela ve beraberindekileri Teşrifat-1 Hariciye Hayreddin Bey karşılamış ve Prenses Gisela’ya İstanbul'da bulundukları sürece mihmandarlıklarına tayin edilen Sultan II. Abdülhamid'in yaverlerinden ve bahriye miralaylarından Mustafa Beyefendi'yi ${ }^{18}$ takdim etmiştir. ${ }^{19}$ Buna mukabil Prenses Gisela, kendilerine gösterilen iltifattan dolayı teşekkürlerinin Sultan'a iletilmesini Hayreddin Bey'den rica etmiştir.

Prenses'i Sirkeci istasyonunda karşılayanlar arasında Almanya Sefareti Müsteşarı Below ile Ataşesi Ayhorn da yer almıştır. ${ }^{20}$ Ardından Istabl-1 Âmire'den tahsis edilen arabalardan birincisine Prenses, oğlu ve yeğeni ile mabeyincisi; ikincincisine mihmandarları ile Almanya sefareti ataşesi binmişlerdir. Doğruca Beyoğlu Tepebaşı'nda bulunan ve Avrupa standartlarına yakınlığıyla anılan Pera Palas Oteli'ne gitmişlerdir. Almanya Büyükelçisi Baron Marschall von Bieberstein (1842-1912) ile eşi, Avusturya Sefareti Maslahatgüzarı Otto ve Avusturya sefareti ataşemiliteri ise Pera Palas Oteli'ne giderek Prenses Gisela'ya hoş geldin ziyaretinde bulunmuşlardır.

Saat sekiz buçukta Prenses Gisela, oğlu Prens Konrad ve mihmandarları Istabl-1 Âmire'den tahsis edilen arabalardan birincisine, mabeyincileri ve Almanya sefareti ataşesi ikincisine binerek Soğuk Çeşme yoluyla Sultan II. Abdülhamid döneminde müze binası olarak tasarlanıp, inşa edilen Müze-i Hümayun'a gitmişlerdir. Burada Müze-i Hümayun Müdürü Osman Hamdi Beyefendi (1842-1910) ile diğer memurlar tarafindan karşılanmışlardır. Daha sonra iadeiziyaret maksadıyla önce Ayas Paşa'da bulunan Almanya sefaretine, ardından Tophane'de, Bostanbaşı'nda bulunan Avusturya sefaretine gitmişlerdir. $^{21}$

\footnotetext{
${ }^{16}$ Bâb-ı Âlî Evrak Odası (BEO), 3288/246587, 7 Ra 1326/9 Nisan 1908; Dâhiliye Nezâreti Mektubî Kalemi (DH.MKT), 1246/1, 7 Ra 1326/9 Nisan 1908, s. 1; Rumeli Müfettişliği Müteferrika Evrakı (TFR.I.M), 20/1934, 27 Mart 1324/9 Nisan 1908; Gönenç, a.g.t., s. 314.

17 "Prinzessin Gisela in Konstantinopel", Das Vaterland (Morgenblatt), nr: 175, 15 Nisan 1908, s. 5.

${ }^{18}$ Prenses'in mihmandarlığında bulunan bahriye miralaylarından Mustafa Hilmi Bey (Yıldız Perakende Evrakı Namei Hümayunlar (Y.PRK.NMH), 10/66, 19 Ra 1326/21 Nisan 1908, s. 4; Gönenç, a.g.t., s. 314), Pera Palas Oteli'ne yakın bir otelde oda kiralamıştır (Y.PRK.NMH, 10/66, 8 Nisan 1324/21 Nisan 1908, s. 5; Gönenç, a.g.t., s. 314). Bu süreçte Mustafa Hilmi Bey otel masraflarından başka mihmandarlıkta bulunmasından kaynaklı dört bin iki yüz yetmiş beş kuruş masraf etmiştir (Y.PRK.NMH, 10/66, 8 Nisan 1324/21 Nisan 1908, s. 5; DH.MKT, 1257/47, 21 Ca 1326/21 Haziran 1908; Gönenç, a.g.t., s. 314).

19 "Prenses Jizel Hazretleri”, Tercüman-ı Hakikat, nr: 9710, 12 Nisan 1908, s. 2.

20 "Prinzessin Gisela in Konstantinopel", Die Zeit (Morgenblatt), nr: 1995, 12 Nisan 1908, s. 6; "Prinzessin Gisela von Bayern in Konstantinopel", Neues Wiener Journal, nr: 5200, 12 Nisan 1908 s. 7; "Türkei", Wiener Zeitung, nr: 86, 12 Nisan 1908, s. 8; "Prenses Jizel Hazretleri", Tercüman-ı Hakikat, nr: 9710, 12 Nisan 1908, s. 2. Bu sırada Avusturya-Macaristan hükûmetinin Dersaadet Büyükelçisi Pallavicini ise izinli olarak Viyana'ya gitmiştir (Tercümanı Hakikat, nr: 9727, 29 Nisan 1908, s. 1). Viyana gazetelerinin istihbaratına göre Pallavicini'nin yokluğunun üç hafta kadar süreceği bildirilmiştir (“Hof- und Personalnachrichten”, Neues Wiener Journal, nr: 5197, 9 Nisan 1908, s. 11; "Avusturya ve Macaristan Sefiri", Tercüman-ı Hakikat, nr: 9710, 12 Nisan 1908, s. 2).

21 "Prenses Jizel Hazretleri", Tercüman-ı Hakikat, nr: 9710, 12 Nisan 1908, s. 2.
} 
12 Nisan sabahı Sultan II. Abdülhamid, Teşrifat-1 Hariciye Hayreddin Beyefendi'yi Prenses Gisela'nın hatırını sormak için Pera Palas Oteli'ne göndermiştir. Buna mukabil Prenses, Sultan II. Abdülhamid'in bu davranışından oldukça memnun olarak teşekkürlerinin Sultan'a arz edilmesini Hayreddin Beyefendi'den rica etmiştir. Daha sonra Prenses Gisela ve Prens Konrad mabeyincileri, Almanya sefareti ataşesi ve mihmandarları ile birlikte kendilerine tahsis edilen arabalarla Pera Palas Oteli'nden ayrılarak dünyanın en eski ve büyük kapalı çarşılarından olan Kapalı Çarşı'yı, bedesteni, antikacıları ve Mısır Çarşısı'nı gezmişlerdir. Pera Palas Oteli'ne dönerek burada yemek yedikten sonra saat sekiz civarında tekrar arabalarla Beyoğlu'ndaki yangın kulesine gitmişlerdir. Ardından bir zamanlar Hristiyan dünyasının en büyük kiliselerinden olan Ayasofya camisini ziyaret etmişlerdir. Osmanlı askerlerinin elbiselerinin sergilendiği Yeniçeri kıyafethanesini, Antik Mısır eseri Dikilitaşı ve çeşme-i dilarayı" görmüşlerdir. Bayezid'e giderek, İstanbul manzarasını bir de buradan seyretmek üzere Bâb-1 Seraskeri meydanındaki yangın kulesine çıkmışlardır. ${ }^{22}$

13 Nisan Pazartesi günü Prenses Gisela, Prens Konrad, Prens Heinrich ve mabeyincileri Hz. Peygamber'in doğumunun kutlandığı törende icra edilen Mevlid Alayı'nda hazır bulunmak üzere üniformalarını giyerek, saat dört buçuk civarında Pera Palas Oteli'nden hareket etmişlerdir. Istabl-1 Âmire'den kendilerine tahsis edilen birinci arabaya Prenses Gisela ile resmî elbiselerini giyinip, nişanlarını takmış olan Teşrifat-1 Hariciye Hayreddin Bey binmişlerdir. Arabanın arkasında atlı olarak Sultan II. Abdülhamid'in maiyetindeki çavuşlardan Tevfik ve Mehmet Mustafa Efendiler bulunmuşlardır. İkinci arabada Prens Konrad, Prens Heinrich ve mihmandarları yer alırken, üçüncü arabaya mabeyincileri ile Almanya sefareti ataşesi binmişlerdir. Prenses Gisela ve beraberindekiler Beyoğlu, Taksim, Ayas Paşa, Dolmabahçe, Beşiktaş yoluyla saat beş civarında Yıldız Sarayı'na, kendilerine tahsis edilen daireye varmışlardır. Almanya Büyükelçisi ile eşi ve sefaret memurlarından bazıları da Yıldız Sarayı'ndaki daireye gelmişlerdir. Misafirler bu daireden icra edilen Mevlid Alayı ile resmigeçidi ayakta izlemiş̧lerdir. Bu sırada Prenses Gisela'nın yanına Tercüman-1 Divan-1 Hümayun ve Teşrifat-1 Umumiye Nazırı Galib Paşa gönderilerek Sultan'ın taltifatı bildirilmiştir. Mevlid Alayı ve resmigeçidin bitiminden sonra Sultan II. Abdülhamid ile Prenses Gisela tercümanlık vazifesini yapan Galib Paşa aracılığıyla resmî surette görüşmüşlerdir. Bu görüşmede Prenses ve Prensler mazhar buyuruldukları taltifattan dolayı Sultan'a teşekkürlerini arz etmişlerdir. Ayrıca icra edilen resmigeçitte askerlerin gösterdikleri intizamdan dolayı bilhassa takdirlerini belirtmişlerdir. Daha sonra misafirler Pera Palas Oteli'ne dönmek üzere Yıldız Sarayı'ndan ayrılmışlardır. ${ }^{23}$

$\mathrm{Bu}$ gelişmelerle ilgili olarak Avusturya basınında ise Mevlid töreninden sonra Prenses Gisela onuruna askerlerin resmigeçitte bulunmaları nadir gerçekleştiğinden dikkate değer görülmüştür. ${ }^{24}$ Ayrıca Sultan'ın Prenses Gisela'yı son derece nazik bir şekilde karşıladığı ve Galib Paşa tarafindan Prenses'e büyük kordonlu mücevherli şefkat nişanı ve beraberindeki iki Prens'e büyük kordonlu birinci rütbeden Osmanlı nişanları takdim edildiği ifade edilmiştir. ${ }^{25}$

\footnotetext{
* Bahsi geçen çeşmenin Sultan III. Ahmed tarafından yaptırılan, Ayasofya Meydanı́ndaki III. Ahmed Çeşmesi olduğu düşünülmektedir. Çeşme hakkında ayrıntılı bilgi için ayrıca bkz. Semavi Eyice, "Ahmed III Çeşmesi", TDV İslâm Ansiklopedisi, II (İstanbul 1989), s. 38.

22 "Prenses Jizel Gizela Hazretleri", Tercüman-ı Hakikat, nr: 9711, 13 Nisan 1908, s. 2.

23 "Prenses Jizel Gizela Hazretleri", Tercüman-ı Hakikat, nr: 9712, 14 Nisan 1908, s. 2.

24 "Prinzessin Gisela in Konstantinopel”, Die Zeit (Morgenblatt), nr: 1998, 15 Nisan 1908, s. 4; "Prinzessin Gisela in Konstantinopel", Das Vaterland (Morgenblatt), nr: 175, 15 Nisan 1908, s. 5.

25 "Prinzessin Gisela in Konstantinopel", Das Vaterland (Morgenblatt), nr: 173, 14 Nisan 1908, s. 5-6; "Prinzessin Gisela von Bayern in Konstantinopel", Neues Wiener Journal, nr: 5202, 14 Nisan 1908, s. 6; "Türkei", Wiener
} 
Öte yandan Sultan II. Abdülhamid Avusturya İmparatoru Franz Joseph'e bir telgraf göndererek; kızı Prenses Gisela ile birlikte akşam yemeği yediklerini, yemekten önce de bir mülakat gerçekleştirdiklerini ve Prenses'in sshhat ve afiyette olduğunu bildirmiş, bu vesile ile İmparator hakkındaki samimi temennilerini dile getirmiştir. ${ }^{26}$ Buna mukabil Avusturya İmparatoru Franz Joseph de bir telgraf ile kızıyla vuku bulan ve unutulması mümkün olmayan bir hatıra bırakan bu mülakattan duyduğu memnuniyetini dile getirmiş, ${ }^{27}$ Prenses Gisela'ya gösterilen "lütufkâraneden dolayl hususi teşekkürlerinin kabul buyurulmasını rica ve bu misafirperverliği zat-ı hümayun-ı mülükanelerinin uzun müddetten beri gösterdikleri samimiyetin bir göstergesi olarak kabul ettiğini ve pek ziyade takdir ile bu hislere kalben iştirak ederek, bundan istifadeyle afiyet ve saadet-i hümayun-ı şahaneleri hakkında en samimi temennilerini tekrar ettiğini" ifade etmiştir. ${ }^{28}$

13 Nisan gecesi ise Almanya Büyükelçisi ile eşi tarafindan Prenses ve Prensler onuruna Ayas Paşa'da bulunan sefarette bir ziyafet düzenlenmiştir. Bu ziyafette Sadrazam Ferid Paşa, Hariciye Nazırı Tevfik Paşa, Tercüman-1 Divan-1 Hümayun ve Teşrifat-1 Umumiye Nazırı Galib Paşa, Teşrifat-1 Hariciye Hayreddin Beyefendi, Tahrirat-1 Hariciye Kâtibi Lütfü Beyefendi, ${ }^{29}$ Sultan II. Abdülhamid'in yaverlerinden Ferik Auler Paşa, Avusturya sefareti maslahatgüzarı, Alman konsolosu ve sefaret memurlar1, Avusturya sefaretinin Taurus vapuru kumandanı, Avusturya sefaret memurlarından bazıları ve Prenses Gisela'nın mihmandarlığında bulunan Mustafa Beyefendi hazır bulunmuşlardır. ${ }^{30}$

14 Nisan'da Prenses Gisela, Prens Konrad ve Prens Heinrich mabeyincileri, Almanya sefareti ataşesi ve mihmandarları ile birlikte Istabl-1 Âmire arabalarıyla Osmanlı Sultanlarının bir dönemki idare merkezi ve resmî ikametgâhı olan Topkapı Sarayı'na gitmişlerdir. Burada ilk olarak Saray Muhafızı Rıza Paşa, ardından Hazine-i Hümayun Kethüdası Edhem, Başkâtibi Ahmed Necati, İkinci Kâtibi Zühdü ve Üçüncü Kâtibi İzzet Beyefendiler tarafından karşılanmışlardır. Müteakiben Hazine-i Hümayun'u ziyaret etmişlerdir. $\mathrm{Bu}$ ziyaretin ardından biraz dinlenen misafirlere şerbet, kahve ve sigara ikram edilmiştir. Daha sonra Prenses ve beraberindekiler Almanya sefaretinde kendileri için düzenlenen çay ziyafetine katılmışlardır.

Saat sekiz civarında Yıldız Sarayı'na gitmişlerdir. Burada Tercüman-1 Divan-1 Hümayun ve Teşrifat1 Umumiye Nazırı Galib Paşa ve Istabl-1 Âmire Müdürü Birinci Ferik Faik Paşa tarafından karşılanmışlardır. Sultan'ın müsaadesi üzerine saray bahçelerini dolaşmışlardır. Daha sonra Sultan II. Abdülhamid döneminde Yıldız Sarayı'nın dış bahçesinde kurulan Çini Fabrikası'na giderek, fabrikanın her tarafını gezmişler ve fabrikanın mükemmeliyeti ile intizamını takdir ettiklerini belirtmişlerdir. Ardından Istabl-ı Âmire'ye giderek saray atlarını görmüşlerdir. Prenses ve Prensler kendilerine gösterilen iltifattan dolayı teşekkürlerinin Sultan'a arz edilmesini Galib Paşa'dan rica ederek Yıldız

Zeitung, nr: 87, 14 Nisan 1908, s. 8; “Nişan”, Tercüman-ı Hakikat, nr: 9718, 20 Nisan 1908, s. 1; "Prinzessin Gisela von Bayern in Konstantinopel", Die Zeit (Morgenblatt), nr: 2017, 5 Mayıs 1908, s. 5.

${ }^{26}$ Y.PRK.NMH, 1/7, t.y.

27 Yıldız Esas Evrakı (Y.EE), 63/51, t.y., s. 2; Gönenç, a.g.t., s. 314.

${ }^{28}$ Y.PRK.NMH, 10/66, 14 Nisan 1908, s. 2; Gönenç, a.g.t., s. 314.

${ }^{29}$ Almanya Büyükelçisi tarafından verilen ziyafette Tahrirat-ı Hariciye Kâtibi Lütfü Beyefendi'nin hazır bulunduğu yazılacakken sehven Teşrifat-ı Hariciye muavinlerinden Memduh Beyefendi'nin yazıldığı belirtilerek söz konusu haber tashih edilmiştir (Tercüman-ı Hakikat, nr: 9713, 15 Nisan 1908, s. 2).

30 "Prenses Jizel Gizela Hazretleri", Tercüman-ı Hakikat, nr: 9712, 14 Nisan 1908, s. 2; "Prinzessin Gisela in Konstantinopel", Das Vaterland (Morgenblatt), nr: 175, 15 Nisan 1908, s. 5; "Prinzessin Gisela in Konstantinopel", Die Zeit (Morgenblatt), nr: 1998, 15 Nisan 1908, s. 6; “Türkei”, Wiener Zeitung, nr: 88, 15 Nisan 1908 , s. 10. 
Sarayı'ndan ayrılmışlardır. Aynı gün Sadrazam Ferid Paşa Pera Palas Oteli'ne giderek Prenses ve Prensleri ziyaret zımnında kartvizitini bırakmıştır.

15 Nisan sabahı Deutsche Bank Direktörü Helfrich, Pera Palas Oteli'ne giderek Prenses'i ziyaret etmiştir. Saat iki buçukta Prenses Gisela, Prens Konrad ve Prens Heinrich mabeyincileri, Almanya sefareti ataşesi ve mihmandarları ile birlikte ${ }^{31}$ Istabl-1 Âmire arabalarıyla Tophane rihtımına gitmişlerdir. Prenses ve beraberindekiler rihtımdan kendilerine tahsis edilen Hidayet istimbotuyla saat üçü beş geçe Haydarpaşa rıhtımına varmışlardır. Burada şimendifer kumpanyası direktörleri ve memurlar tarafından karşılanmışlardır. Ardından kendilerine tahsis edilen trene binerek Hereke'ye gitmişlerdir. Hususi trende, Anadolu Osmanlı Şimendifer Kumpanyası Umumi Müdürü Hügnen, Deutsche Bank Direktörü Helfrich ve Müdür Kiryaku Arstidi Efendi tarafindan Prenses ve Prensler şerefine mükellef bir sabah ziyafeti verilmiştir.

Beşe çeyrek kala tren Hereke'ye varmıştır. Prenses ile beraberindekiler Fabrika-i Hümayun ve Hazine-i Hassa-i Şahane Mefruşat Müdürü Hacı Akif Bey Efendi ile diğer memurlar tarafindan karşılanarak doğruca Hereke Fabrikası'na gitmişlerdir. Osmanlı dokuma sanayisinde oldukça önemli bir yere sahip olan bu fabrikanın her tarafını, çuha, fes ve nadide kumaşlar imal edilen dairelerini tek tek gezmişlerdir. Gördükleri intizam ve mükemmeliyet karşısında takdirlerini belirtmişlerdir. Ayrıca fabrikada gördükleri bu mükemmeliyeti her yerde dile getirerek, takdirle övüp, yâd edeceklerini beyan etmişlerdir. ${ }^{32}$ Fabrikada Prenses Gisela'ya halı, seccade, kumaş gibi çeşitli ürünler hediye edilmiştir. ${ }^{33}$ Misafirler saat sekizde fabrika memurları tarafindan uğurlanarak, fabrikadan ayrılmışlardır. Hereke'den dönerlerken Gebze istasyonunda durarak, deniz kenarında eski eserlerden olan kaleyi görmüşlerdir. Biraz gezintiden sonra tekrar trene binmişlerdir. Hususi tren içinde kumpanya tarafından bir çay ziyafeti düzenlenmiştir. Haydarpaşa istasyonuna varan misafirler saat on bir buçukta Haydarpaşa rıhtımında bulunan Hidayet istimbotuyla Galata'daki Aziziye Karakolu'nun rıhtımına varmışlardır. Buradan Istabl1 Âmire arabalarıyla Pera Palas Oteli'ne dönmüşlerdir. ${ }^{34}$

16 Nisan sabahı Prenses Gisela, Prens Konrad ve Prens Heinrich mabeyincileri, Almanya sefareti ataşesi ve mihmandarları ile birlikte Kapalı Çarşı'yı, bedesteni ve Mahmutpaşa'yı gezmişler ve alışveriş yapmışlardır. Öğle yemeğini Pera Palas Oteli'nde yedikten sonra Istabl-1 Âmire arabalarıyla Tophane rıhtımına gitmişlerdir. Prenses Gisela ve beraberindekiler buradan Hidayet istimbotuyla Haydarpaşa rıhtımına çıkmışlardır. Arabalarla Karacaahmet Kabristanı yoluyla Üsküdar İnadiye'deki Perşembe Tekkesi'ne gitmişler ve yapılan tarikat ayinini izlemişlerdir. ${ }^{35}$

17 Nisan sabahı Prenses Gisela, Prens Konrad ve Prens Heinrich mabeyincileri ve Almanya sefareti ataşesi ile birlikte Beyoğlu'ndaki Katolik Santa Maria Kilisesi'ne giderek icra edilen ruhani ayinde hazır bulunmuşlardır. ${ }^{36}$ Daha sonra Prenses Gisela, Prens Konrad ve Prens Heinrich refakatlerinde

\footnotetext{
31 "Prenses Gizela Hazretleri", Tercüman-ı Hakikat, nr: 9713, 15 Nisan 1908, s. 1.

32 "Prenses Gizela Hazretleri", Tercüman-ı Hakikat, nr: 9714, 16 Nisan 1908, s. 2.

${ }^{33}$ Yıldız Mütenevvi Maruzat Evrakı (Y.MTV), 310/23, 22 R 1326/24 Mayıs 1908; Abdulkadir Buluş, "Osmanlı Tekstil Sanayi ve Hereke Halı Fabrikası" (doktora tezi, İstanbul Üniversitesi, 2000), 195.

34 "Prenses Gizela Hazretleri", Tercüman-ı Hakikat, nr: 9714, 16 Nisan 1908, s. 2.

35 "Prenses Gizela Hazretleri”, Tercüman-ı Hakikat, nr: 9715, 17 Nisan 1908, s. 1. XVIII. yy'a ait bir Celvetî tekkesi olan Bandırmalızâde Tekkesi hakkında ayrıca bkz. M. Baha Tanman, Hasan Kâmil Yılmaz, "Bandırmalızâde Tekkesi", TDV İslâm Ansiklopedisi, V (İstanbul 1992), s. 54-55.

36 "Prinzessin Gisela in Konstantinopel", Das Vaterland (Abendblatt), nr: 178, 16 Nisan 1908, s. 3; "Prinzessin Gisela in Konstantinopel", Die Zeit (Abendblatt), nr: 1999, 16 Nisan 1908, s. 2; "Prenses Gizela Hazretleri", Tercüman-ı Hakikat, nr: 9716, 18 Nisan 1908, s. 1.
} 
mihmandarları ile birlikte Galata Mevlevihanesi'ni ziyaret etmişlerdir. Ardından Kağıthane’ye giderek manzarayı seyretmişler ve mimari yönden Avrupa'daki saraylara benzeyen Çağlayan Kasrı'nı görmüşlerdir. ${ }^{37}$

18 Nisan sabahı Prenses Gisela, Prens Konrad ve Prens Heinrich mabeyincileri, Almanya sefareti ataşesi ve mihmandarları ile birlikte Istabl-1 Âmire arabalarıyla Aksaray, Samatya, tramvay yolu üzerinden Yedikule'ye kadar gitmişlerdir. Buradan sur dışına çıkarak Istabl-1 Âmire'den gönderilen atlara binmişler ve sur dışını seyretmişlerdir. Müteakiben Defterdar iskelesine ve oradan arabalarla Bâbıâli'ye gitmişlerdir. Prens Konrad ve Prens Heinrich Sadrazam'a kartvizitlerini bıraktıktan sonra Pera Palas Oteli'ne dönerek öğle yemeği yemişlerdir. Ardından misafirler refakatlerinde mihmandarları ile birlikte Sirkeci'deki Celal Bey Hanı'nın karşısında bulunan Hacı Gaffur Efendi'nin halı mağazasına giderek alışveriş yapmışlardır. ${ }^{38}$

19 Nisan sabahı Prenses Gisela, Prens Konrad ve Prens Heinrich mabeyincileri ve Almanya sefareti ataşesi ile birlikte Istabl-1 Âmire arabalarıyla Santa Maria Kilisesi'ne giderek icra edilen ruhani ayinde hazır bulunmuşlardır. Saat beşte Prenses ve beraberindekiler refakatlerinde mihmandarlarıyla Tophane rıhtımına gitmişlerdir. Buradan Hidayet istimbotuyla Moda'ya geçerek Baron Schwanberg tarafından kendileri için düzenlenen ziyafete katılmışlardır. ${ }^{39}$

20 Nisan'da Prenses Gisela, rahatsızlığı nedeniyle Bursa'ya yapacağı geziyi ertelemiştir. ${ }^{40}$ Sabah saatlerinde Avusturya sefaretine giderek, Maslahatgüzar Otto'yu ziyaret ettikten sonra oteline dönüp istirahat etmiştir. Prenses'in rahatsız olduğunun Sultan II. Abdülhamid tarafindan duyulması üzerine Erkan-1 Harbiye Müşiri Abdullah Paşa ile Teşrifat-1 Hariciye Hayreddin Beyefendi saat yedi civarında Pera Palas Oteli'ne gönderilerek Prenses'in durumunu sormuşlardır. Hafif şekilde nezle olan Prenses, Sultan'ın bu davranışından dolayı teşekkürlerinin Sultan'a iletilmesini Abdullah Paşa ve Hayreddin Beyefendi'den rica etmiştir. ${ }^{41}$

Saat sekizde Prens Heinrich; Prenses Gisela ve Prens Konrad'a resmen veda edip, Sirkeci istasyonuna giderek Ekspres treniyle İstanbul'dan ayrılmıştır. Prens'i istasyondan resmî olarak Teşrifatı Hariciye Hayreddin Beyefendi uğurlamıştır. Bu sırada Prens, Hayreddin Beyefendi'den İstanbul'da bulundukları sürece kendilerine gösterilen misafirperverlikten dolayı teşekkürlerinin Sultan'a arz

37 "Prenses Gizela Hazretleri", Tercüman-ı Hakikat, nr: 9715, 17 Nisan 1908, s. 1; "Prenses Gizela Hazretleri", Tercüman-ı Hakikat, nr: 9716, 18 Nisan 1908, s. 1; Prenses Gisela'nın eşi Bavyera Prensi Leopold’un Paskalya'dan sonra İstanbul'a geleceği Avusturya basınında dile getirilmişse de ("Prinzessin Gisela in Konstantinopel", Das Vaterland (Abendblatt), nr: 178, 16 Nisan 1908, s. 3; "Prinzessin Gisela in Konstantinopel”, Die Zeit (Abendblatt), nr: 1999, 16 Nisan 1908, s. 2; "Prenses Gizela Hazretleri", Tercüman-ı Hakikat, nr: 9715, 17 Nisan 1908, s. 1) gelmediği anlaşılmaktadır ("Prenses Gizela Hazretleri”, Tercüman-ı Hakikat, nr: 9717, 19 Nisan 1908, s. 1).

38 "Prenses Gizela Hazretleri", Tercüman-ı Hakikat, nr: 9717, 19 Nisan 1908, s. 1.

${ }^{39}$ Y.PRK.NMH, 10/66, 19 Ra 1326/21 Nisan 1908, s. 4; "Prenses Gizela Hazretleri”, Tercüman-ı Hakikat, nr: 9718 , 20 Nisan 1908, s. 1.

${ }^{40}$ Avusturya basınında şiddetli fırtına nedeniyle İmparatorluk yatı Stambul ile Bursa'ya yapılması planlanan gezinin gerçekleştirilemediği ifade edilmektedir ("Prinzessin Gisela von Bayern in Konstantinopel", Das Vaterland (Morgenblatt), nr: 185, 22 Nisan 1908, s. 4; "Türkei", Wiener Zeitung, nr: 93, 22 Nisan 1908, s. 6).

41 "Prenses Gizela Hazretleri", Tercüman-ı Hakikat, nr: 9719, 21 Nisan 1908, s. 1; "Die Erkrankung der Prinzessin Gisela", Die Zeit (Morgenblatt), nr: 2004, 22 Nisan 1908, s. 4; "Erkrankung der Prinzessin Gisela von Bayern in Konstantinopel", Neues Wiener Journal, nr: 5209, 22 Nisan 1908, s. 7. 
edilmesini rica etmiştir. Prens'i uğurlayanlar arasında Almanya sefareti müsteşarı ile sefaret ataşesi ve Avusturya sefaretinde görevli bazı kişiler de yer almışlardır. ${ }^{42}$

21 Nisan sabahı Prenses Gisela ve Prens Konrad mabeyincileri, Almanya sefareti ataşesi ve mihmandarları ile birlikte Fatih ve Bizans döneminde kilise olan Kariye-i Atik camilerini ziyaret etmişlerdir. Pera Palas Oteli'nde öğle yemeği yemelerinin ardından arabalarla Tophane rıhtımına, oradan Hidayet istimbotuyla manzarasını seyretmek üzere Boğaziçi'ne ve Tarabya'daki Almanya sefaretine gitmişlerdir. ${ }^{43}$

22 Nisan akşamı Prenses Gisela'nın büyük oğlu Prens Georg, Mesajeri kumpanyasının Nijer vapuruyla İstanbul'a gelmiştir. Vapuru Galata rıhtımına yanaşmıştır. Prens Georg'u karşılamak üzere Teşrifatı Hariciye Hayreddin Beyefendi gönderilmiştir. Buna mukabil Prens, kendisine gösterilen iltifattan dolayı teşekkürlerini Sultan'a arz etmesini Hayreddin Beyefendi'den rica etmiştir. Prens'i karşılayanlar arasında kardeşi Prens Konrad ile birlikte mabeyincileri, Almanya sefareti müsteşarı ve ataşesi de yer almışlardır. Karşılamadan sonra Istabl-1 Âmire'den tahsis edilen arabalardan birincisine Prens Georg, Prens Konrad ve Hayreddin Beyefendi, ikincisine Prens Georg'un maiyeti, mabeyincileri, Almanya sefareti müsteşarı ve ataşesi binmişlerdir. Birinci arabanın arkasında çavuşlar Tevfik ve Mehmed Mustafa Efendiler atlı olarak Pera Palas Oteli'ne gitmişlerdir. Almanya büyükelçisi ile Avusturya sefareti maslahatgüzarı Pera Palas Oteli'ne giderek Prens Georg'a hoş geldin ziyaretinde bulunmuşlardır. ${ }^{44}$

23 Nisan sabahı Prenses Gisela, Prens Georg ve Prens Konrad mabeyincileri, Almanya sefareti ataşesi ve mihmandarları ile birlikte Kapalı Çarşı’yı gezip alışveriş yapmışlardır. Bâbıâli’ye giden Prens Georg, Sadrazam'a kartvizitini bırakmıştır. Ardından Bâbıâli caddesi yoluyla Şekercibaşı Hacı Bekirzade Ali Muhsin Bey'in dükkânına giderek şeker almıştır. Prens Georg daha sonra Almanya sefaretine gitmiş ve Almanya Büyükelçisini ziyaret etmiştir. Pera Palas Oteli’nde öğle yemeği yedikten sonra Prenses, oğulları ve beraberindekiler Hidayet istimbotuyla Eyüp'e gitmişlerdir. Haliç’te bulunan Osmanlı gemilerini görmüşlerdir. ${ }^{45}$

24 Nisan'da Prenses Gisela, Prens Georg ve Prens Konrad mabeyincileri, Almanya sefareti ataşesi ve mihmandarları ile birlikte selamlık resmini izlemek üzere Istabl-1 Âmire arabalarıly saat beş buçukta Yıldız Sarayı'na varmışlardır. Almanya büyükelçisi, sefaret müsteşarı ve baştercümanı da Yıldız Sarayı'na gelmişlerdir. Prenses, oğulları ve beraberindekiler selamlık resmini kendileri için hazırlanan hususi daireden izlemişlerdir. ${ }^{46} \mathrm{Bu}$ sırada kendileriyle Tercüman-1 Divan-1 Hümayun ve Teşrifat-1 Umumiye Nazırı Galib Paşa ilgilenmiştir. Misafirlere tertip edilen mükemmel bir büfeden pasta, şekerleme, bisküvi, çay vesair ikram edilmiştir. ${ }^{47}$ Cuma selamlığından sonra Sultan II. Abdülhamid, Almanya büyükelçisi eşliğigle Prenses Gisela'yı, Prens Georg'u ve Prens Konrad'ı kabul etmiştir. ${ }^{48}$

\footnotetext{
42 "Fehametlü Prens Henri Hazretleri", Tercüman-ı Hakikat, nr: 9719, 21 Nisan 1908, s. 1.

43 "Prenses Gizela Hazretleri", Tercüman-ı Hakikat, nr: 9720, 22 Nisan 1908, s. 1.

44 "Fehametlü Prens Georg Hazretleri", Tercüman-ı Hakikat, nr: 9721, 23 Nisan 1908, s. 1-2.

45 "Prenses Gizela Hazretleri", Tercüman-ı Hakikat, nr: 9722, 24 Nisan 1908, s. 1.

46 "Prenses Gizela Hazretleri", Tercüman-ı Hakikat, nr: 9723, 25 Nisan 1908, s. 1; "Prinzessin Gisela in Konstantinopel", Die Zeit (Morgenblatt), nr: 2007, 25 Nisan 1908, s. 5; "Türkei”, Wiener Abendpost, nr: 96, 25 Nisan 1908, s. 2.

47 "Prenses Gizela Hazretleri", Tercüman-ı Hakikat, nr: 9723, 25 Nisan 1908, s. 1.

48 "Prenses Gizela Hazretleri", Tercüman-ı Hakikat, nr: 9723, 25 Nisan 1908, s. 1; "Prinzessin Gisela in Konstantinopel”, Die Zeit (Morgenblatt), nr: 2007, 25 Nisan 1908, s. 5; “Türkei”, Wiener Abendpost, nr: 96, 25 Nisan 1908, s. 2.
} 
Daha önce mücevherli Şefkat nişanı verilmiş olan Prenses Gisela büyük kordonlu mücevherli Mecidiye $^{49}$, keza daha önce büyük kordonlu Osmanlı nişanı verilmiş olan Prens Konrad mücevherli Mecidiye ve Prens Georg mücevherli İftihar nişanı ile taltif edilmiştir. ${ }^{50}$

Sultan ile Prenses arasında gerçekleştirilen görüşmede tercümanlık vazifesi Galib Paşa tarafından yapılmıştır. Bu görüşme sırasında Prenses ve Prensler kendilerine gösterilen iltifattan dolayı Sultan'a teşekkürlerini bir kez daha arz etmişlerdir. Görüşmeden sonra Istabl-1 Âmire arabalarından birincisine Prenses Gisela, Prens Georg ve mihmandarları, ikincisine Prens Konrad ve mabeyincileri ve üçüncüsüne Almanya sefareti ataşesi binerek Pera Palas Oteli'ne dönmüşlerdir. Daha sonra Prens Georg ile Prens Konrad refakatlerinde mihmandarları ile birlikte Galata Kulesi'ne gitmişler ve kuleyi gezmişlerdir.

Geceleyin Almanya Büyükelçisi tarafından Prenses şerefine sefarette bir ziyafet verilmiştir. $\mathrm{Bu}$ ziyafette Prenses ve oğulları, mabeyincileri, mihmandarları, Avusturya sefareti ataşemiliteri ve baştercümanı, Almanya konsolosu, Almanya sefareti ataşemiliteri ve baştercümanı, Almanya Sefareti maiyetine memur Lorlei vapuru kumandanı ile bazı sefaret görevlileri ve diğer bazı kişiler hazır bulunmuşlardır. $^{51}$

25 Nisan sabahı Prens Georg ve Prens Konrad çavuşlardan Tevfik ve Mehmet Mustafa efendilerin refakatinde Müze-i Hümayûn'u gezmişler ve ardından Kapalı Çarşı'ya gitmişlerdir. Daha sonra Prenses Gisela, Prens Georg ve Prens Konrad mabeyincileri, Almanya sefareti ataşesi ve mihmandarları ile birlikte Hidayet istimbotuyla Samatya açıklarına kadar giderek bir deniz gezintisi yapmışlardır.

Saat on ikide onurlarına düzenlenen gala yemeğine katılmak üzere Yıldız Sarayı'na gitmişlerdir. Bu ziyafette sadrazam, serasker, bahriye ve hariciye nazırları, Tophane-i Amire müşiri, Almanya büyükelçisi ile eşi, Almanya sefareti müsteşarı, Avusturya sefareti maslahatgüzarı, Almanya ve Avusturya sefaret görevlileri ile Mabeyn-i Hümayun görevlileri hazır bulunmuşlardır. Ziyafet süresince Mabeyn-i Hümayun Orkestrası çalarken, ${ }^{52}$ yemekten sonra bir de tiyatro gösterisi yapılmıştır. Gala yemeği sırasında Sultan II. Abdülhamid, Avusturya Sefareti Maslahatgüzarı Otto’yu onurlandırmış ve kendisine birinci rütbeden Osmanlı nişanı verilmiştir.

\footnotetext{
${ }^{49}$ Prenses ve Prenslerin çeşitli nişanlar ve hediyelerle taltif edilmeleri Avusturya basınında da geniş yer bulmuştur. Bu hususta kadınlar için en yüksek rütbe mücevherli özel Mecidiye nişanının o zamana kadar toplam da altı yabancıya verildiğine dikkat çekilmiştir. Bunlardan birinin de Franz Joseph'in torunu, Veliaht Arşidük Rudolf'un kızı Arşidüşes Elisabeth Windisch-Grätz (1883-1963) olduğu ve kendisinin İstanbul ziyareti sırasında bu nişanla taltif edildiği belirtilmiştir ("Prinzessin Gisela von Bayern in Konstantinopel”, Das Vaterland (Abendblatt), nr: 194, 27 Nisan 1908, s. 3; "Prinzessin Gisela in Konstantinopel", Neues Wiener Journal, nr: 5214, 27 Nisan 1908, s. 2). Bir başka haberde ise Prenses Gisela'ya verilen nişanı o zamana kadar Alman İmparatoriçesinin, kızının ve İmparator Franz Josef'in torununun aldı̆̆ ifade edilmiştir ("Prinzessin Gisela von Bayern in Konstantinopel”, Die Zeit (Morgenblatt), nr: 2017, 5 Mayıs 1908, s. 5).

50 "Hofnachricht", Wiener Abendpost, nr: 96, 25 Nisan 1908, s. 2; "Prinzessin Gisela in Konstantinopel", Die Zeit (Morgenblatt), nr: 2007, 25 Nisan 1908, s. 5; "Prinzessin Gisela in Konstantinopel”, Neues Wiener Journal, nr: 5214, 27 Nisan 1908, s. 2; "Türkei", Wiener Abendpost, nr: 97, 27 Nisan 1908, s. 2; "Prinzessin Gisela von Bayern in Konstantinopel", Das Vaterland (Abendblatt), nr: 194, 27 Nisan 1908, s. 3; "Nişan", Tercüman-ı Hakikat, nr: 9727, 29 Nisan 1908, s. 1; "Prinzessin Gisela von Bayern in Konstantinopel”, Die Zeit (Morgenblatt), nr: 2017,5 Mayıs 1908, s. 5. Prenses Gisela'nın, oğullarının ve yeğeninin aldığı hediyeler arasında en saf dört cins Arap atı da yer almıştır ("Prinzessin Gisela von Bayern in Konstantinopel”, Die Zeit (Morgenblatt), nr: 2017, 5 Mayıs 1908, s. 5).

51 "Prenses Gizela Hazretleri", Tercüman-ı Hakikat, nr: 9723, 25 Nisan 1908, s. 1.

52 "Prenses Gizela Hazretleri", Tercüman-ı Hakikat, nr: 9724, 26 Nisan 1908, s. 1.
} 
Prenses Gisela ve Prens Konrad Pazartesi günü İstanbul'dan ayrılacaklarından Sultan'a resmî vedalarını da bu vesile ile bildirmişlerdir. İstanbul'da bulundukları sürece kendilerine gösterilen iltifattan dolayı teşekkürlerini yineleyerek, Sultan'ın müsaadesi üzerine saat iki civarında saraydan ayrılmışlardır. ${ }^{53}$ Prenses Gisela'nın nişanla taltif edildiğini haber alan İmparator Franz Joseph ise kızının İstanbul'da ikameti müddetince gösterilen lütuftan dolayı Sultan II. Abdülhamid'e teşekkürlerini arz etmiş ve bundan istifade ile samimi surette iyi dileklerini tekrar etmiştir. ${ }^{54}$

26 Nisan sabahı Prenses Gisela, Prens Georg ve Prens Konrad mabeyincileri, Almanya sefareti ataşesi ve mihmandarları ile birlikte Istabl-1 Âmire arabalarıyla Tophane rıhtımına gitmişlerdir. Buradan Hidayet istimbotuyla Rumeli sahilini takiben Boğaziçi'ne doğru ilerlemişlerdir. Ardından Küçüksu'ya geçip, Batı tarzı mimarisiyle dikkat çeken Küçüksu Kasrı'nı gezmişlerdir. Daha sonra Prenses ve oğulları Almanya sefaret gemisi Lorlei'de şereflerine verilen çay ziyafetine katılmışlardır. Bu ziyafette Almanya büyükelçisi ve eşi, sefaret müsteşarı, ataşemiliteri ve baştercümanı, Deutsche Bank Direktörü Helfrich, Umumi Müdür Hügenen ve Avusturya sefareti maiyet vapuru kumandanı ile mihmandar Mustafa Beyefendi yer almışlardır.

Aynı gece Prenses Gisela da Pera Palas Oteli'nde Almanya büyükelçisi şerefine bir veda ziyafeti düzenlemiştir. Bu ziyafete Prenses Gisela ve oğulları, Almanya büyükelçisi ve eşi, Almanya sefareti müsteşarı, baştercümanı ve ataşemiliteri, Avusturya sefareti maslahatgüzarı ve baştercümanı, Prenses Gisela'nın maiyeti ve mihmandarı katılmışlardır. Sultan II. Abdülhamid tarafından da Tercüman-1 Divan-1 Hümayun ve Teşrifat-1 Umumiye Nazırı Galib Paşa Pera Palas Oteli'ne gönderilmiş ve Sultan'ın iltifatı kendilerine tebliğ edilmiştir. Buna mukabil Prenses Gisela ve oğulları bu suretle nail oldukları iltifattan dolayı teşekkürlerinin Sultan'a arz edilmesini Galib Paşa'dan rica etmişlerdir. ${ }^{55}$

\section{Prenses Gisela'nın İstanbul'dan Ayrılışı ve Prens Georg'un Devam Eden İstanbul Günleri}

27 Nisan'da Prenses Gisela ve küçük oğlu Prens Konrad İstanbul'dan ayrılarak Şark Ekspresi ile Viyana'ya gitmişlerdir. İstasyonda Sultan II. Abdülhamid adına kendilerini uğurlamak üzere tercüman1 divan-1 hümayun ve teşrifat-1 umumiye nazırı, erkân-1 harbiye müşiri, sadrazam ve hariciye nazırının yardımcıları hazır bulunmuşlardır. Prenses Gisela, kendilerine gösterilen büyük onur ve yakınlığın yanı sıra verilen çeşitli hediyeler ve olağanüstü misafirperverlik için Sultan'ın temsilcilerine tekrar teşekkürlerini bildirmiştir. Elçilik üyeleri ile birlikte Almanya büyükelçisi ve Avusturya maslahatgüzarı da Prenses ve oğlunu uğurlayanlar arasında yer almışlardır. ${ }^{56}$

İstanbul seyahatine devam eden Prens Georg ise 28 Nisan sabah saat iki civarında yaveri ve mihmandarı ile birlikte Hamidiye Etfal hastanesini ziyaret etmiştir. Kendilerini hastane Baştabibi Ferik

\footnotetext{
53 "Prenses Gizela Hazretleri”, Tercüman-ı Hakikat, nr: 9724, 26 Nisan 1908, s. 1; "Prinzessin Gisela von Bayern in Konstantinopel", Das Vaterland (Abendblatt), nr: 194, 27 Nisan 1908, s. 3.

54 Y.PRK.NMH, 10/66, 25 Nisan 1908, s. 6; Gönenç, a.g.t., s. 314.

55 "Prenses Gizela Hazretleri", Tercüman-ı Hakikat, nr: 9725, 27 Nisan 1908, s. 1.

56 "Hofnachrichten", Das Vaterland (Morgenblatt), nr: 195, 28 Nisan 1908, s. 4; "Prinzessin Gisela in Konstantinopel", Die Zeit (Morgenblatt), nr: 2010, 28 Nisan 1908, s. 4; "Abreise der Prinzessin Gisela von Konstantinopel", Neues Wiener Journal, nr: 5215, 28 Nisan 1908, s. 4. Prenses Gisela ve oğlu Prens Konrad 29 Nisan sabahı Viyana'ya varmışlardır ("Hofnachrichten", Das Vaterland (Abendblatt), nr: 198, 29 Nisan 1908, s. 3). 29 Nisan'da İmparator Franz Jozef bir aile yemeği düzenlemiştir. Bu yemeğe Prenses Gisela ve Prens Konrad ile birlikte Münih'ten gelen Prens Leopold ve burada yaşayan büyük kızları Prenses Elisabeth Marie ile eşi Kont Seefried katılmışlardır. Böylece Prenses Gisela büyük kızıyla da bu vesileyle görüşmüştür ("Aus hofkreisen”, Wiener Salonblatt, nr: 19, 9 Mayıs 1908, s. 2). Prenses Gisela ailesiyle birlikte 30 Nisan akşamı Münih'e gitmiştir ("Hofnachrichten", Das Vaterland (Abendblatt), nr: 198, 29 Nisan 1908, s. 3).
} 
İbrahim Paşa, İkinci Tabip Mirliva Süleyman Nuri Paşa, Müdür Miralay Faik Beyefendi ve diğer doktorlar ile memurlar karşılamışlardır. Misafirler merkez binada bulunan misafir salonuna alınarak bir süre burada istirahat ettikten sonra röntgen dairesinin bulunduğu üçüncü pavyona gidilmiştir. Bu esnada sekiz yaşında hasta bir kız çocuğu Prens Georg'a bir çiçek buketi takdim etmiş ve Prens Georg oldukça memnun olarak kız çocuğunun başını okşamıştır. Bu pavyonda Operatör Binbaşı Rasih Bey tarafından Prens Georg'a hastanede iyileştirilen hastalara ait çeşitli röntgen filmleri gösterilmiştir. Müteakiben baştabip ve ikinci tabip tarafindan dört, altı ve yedinci pavyonlar ile sanatoryum gezdirilmiştir. Prens Georg hastanenin haricî ve dâhilî hastalıklar pavyonlarında gördüğü intizamı ve sıhhi temizliği takdirle izlemiştir. Daha sonra merkez binanın önünde fotoğraf çekilerek, tekrar misafirlere mahsus salona dönülmüş ve burada bir çay ziyafeti verilmiştir. Ziyafetten sonra baştabip tarafindan Prens Georg'a hastanenin İstatistik Tıp Mecmuası ile çeşitli manzaralarını gösteren bir kıta albüm takdim edilmiştir. Buna mukabil Prens Georg oldukça memnun olarak Paşa'ya tekrar ve tekrar hoşnutluğunu beyan etmiştir. Baştabip ve ikinci tabip tarafından kendisine verilen fennî açıklamayı dikkatle dinleyen Prens Georg, bakteriyoloji ve kimya laboratuvarının alet ve edevatça mükemmeliyetini de takdirle karşılamıştır.

Saat üç buçukta, memnuniyet ve dostluk hislerini gösteren Prens Georg; baştabip, ikinci tabip ve diğer doktorlar ile memurlar tarafından hakkında layık olduğu saygı gösterilerek uğurlanmıştır.

Saat dörtte refakatinde mabeyincisi, mihmandarı ve Almanya sefareti ataşesi ile birlikte Topkapı Sarayı'na varmıştır. İlk olarak Saray Muhafızı Rıza Paşa tarafından karşılanmış ve Başkâtip Ahmet Necati Beyefendi ile diğer memurlar tarafindan kendisine gerekli ihtiram gösterilmiştir. Hazine-i Hümayun ziyaretinin ardından misafirlere şerbet, kahve ve sigara ikram edilmiştir. Osmanlı klasik dönem mimarisinin önemli eserlerinden biri olan Bayezid Camisi ile Ayasofya Camisi de Prens Georg'un ziyaret ettiği yerler arasında olmuştur.

Saat sekiz buçukta Prens Georg Hidayet istimbotuyla Üsküdar'a geçerek, arabalarla Bulgurlu’ya kadar gidip, İstanbul manzarasını seyretmiştir. Ardından Beylerbeyi'ne geçip, yine istimbota binerek deniz havası almıştır. ${ }^{57}$

29 Nisan sabahı Prens Georg mabeyincisi, mihmandarı ve Almanya sefareti ataşesi ile birlikte İstanbul adalarının en büyügü olan Büyükada’ya gitmiştir. Bu adada bulunan Ayayorgi Kilisesi’ni gezmiştir. Otel Imperial'de yemek yedikten sonra istimbotla İstanbul adalarının en yeşili olan Heybeliada'ya çıkmış ve çamlık mahalde gezinti yapmıştır. Daha sonra İstanbul tarafina geçerek, Kapalı Çarşı' yı ve bedesteni gezmiştir. ${ }^{58}$

30 Nisan sabahı Prens Georg mabeyncisi, mihmandarı ve Almanya sefareti ataşesi ile birlikte Istabl1 Âmire arabalarıla Yedikule'ye gitmiştir. Burada at binip, sur dışını seyretmiştir. Öğle yemeğini Pera Palas Oteli'nde yiyen Prens Georg, daha sonra Kapalı Çarşı'ya giderek alışveriş yapmıştır. ${ }^{59}$

1 Mayıs'ta Prens Georg mabeyincisi ve mihmandarı ile birlikte Istabl-1 Âmire arabalarıla önce Tophane rihtımına ve buradan Hidayet istimbotuyla Tarabya'ya geçip, Almanya sefaretinin bahçesine gitmiştir. Bahçede bir süre dolaştıktan sonra tekrar aynı istimbotla Büyükdere ve Mesarburnu'na kadar bir gezinti yapmıştır. Pera Palas Oteli'nde yemek yedikten sonra Istabl-1 Âmire arabalarıyla Sultan Selim türbesi ile camisini ve Sultan Mehmet Han türbesi ile camisini ziyaret etmiştir. Ardından Roma

\footnotetext{
57 “Hamidiye Etfal Hastahane-i Âlisini Ziyaret”, Tercüman-ı Hakikat, nr: 9727, 29 Nisan 1908, s. 1.

58 "Prens Georg Hazretleri", Tercüman-ı Hakikat, nr: 9728, 30 Nisan 1908, s. 1.

59 "Prens Georg Hazretleri”, Tercüman-ı Hakikat, nr: 9729, 1 Mayıs 1908, s. 2.
} 
dönemine ait Bozdoğan su kemerlerini görmüştür. Müteakiben Sultan II. Mahmud'un türbesini ziyaret etmiştir. ${ }^{60}$

2 Mayıs $^{61}$ sabahı Prens Georg mabeyincisi, mihmandarı, Almanya sefareti ataşesi, Meklemburgstrelitz Büyük Dukası'nın oğlu Dük Karl Borwin ve Kont Eisenburg ile birlikte trenle Eskişehir'e gitmiştir. ${ }^{62}$ Bu seyahatte Anadolu Şimendifer Direktörü de yer almıştır. Akşam saat on birde Eskişehir'e varan Prens Georg ve beraberindekiler, hükûmet ve şimendifer memurları tarafindan karşılanmışlardır. İstasyondan arabalara binerek Şeyh Edebali'nin türbesini ziyaret etmişlerdir. Daha sonra hükûmet dairesine gitmişler ve akşam şereflerine verilen çay ziyafetine katılmışlardır. Ardından tekrar arabalarla o civardaki kaplıcaları gezdikten sonra şimendifer istasyonuna gitmişlerdir. Burada Alman muteberanı tarafından şereflerine bir konser verilmiştir. Prens Georg ile beraberindekiler akşam yemeğini kendilerine tahsis edilen trende yemişler ve sabah saat ikide İstanbul'a varmışlardır. Pera Palas Oteli'nde biraz dinlendikten sonra Prens Georg yaveri ile birlikte Istabl-1 Âmire arabasıyla Ayas Paşa' da bulunan Almanya sefaretine gitmiştir. Büyükelçi Marschall'a resmî veda zımnında kartvizitini bırakmıştır. Ardından Dolmabahçe'ye inerek, Hidayet istimbotuyla Lorlei gemisine gitmiş ve gemi süvarisine resmî vedada bulunmuştur. Saat sekizde Prens Georg mabeyincisi ve mihmandarı ile birlikte Ayasofya Camisi'ni, Müze-i Hümayunu ve Çinili Köşkü ziyaret etmiştir. Ardından Bâbıâli’ye giderek sadrazamı ziyaretle resmî vedada bulunmuştur. ${ }^{63}$

\section{Prens Georg'un İstanbul'dan Ayrılışı}

4 Mayıs sabahı Prens Georg yaveri, mihmandarı ve Almanya sefareti ataşesi ile birlikte Istabl-1 Âmire arabalarıyla Tophane rıhtımına ve oradan Hidayet istimbotuyla Beykoz'a giderek Beykoz çayırını gezmiştir. Öğle yemeğini Pera Palas Oteli’nde yedikten sonra saat yedi buçukta Istabl-1 Âmire arabalarıyla Sirkeci istasyonuna gitmiştir.

Prens Georg'u yolcu etmek üzere Sultan II. Abdülhamid tarafından Teşrifat-1 Hariciye Hayreddin Beyefendi Sirkeci istasyonuna gönderilmiştir. Sadrazam tarafından Sadrazam Tercümanı Ahmet Muhtar Beyefendi ve Hariciye Nazırı Tevfik Paşa tarafında da Hariciye Nezareti Tercümanı Sadettin Beyefendi Sirkeci istasyonuna gönderilerek resmî uğurlamada bulunmuşlardır. Ayrıca Almanya sefareti müsteşarı ile baştercümanı, başkâtibi, general konsolosu, diğer sefaret görevlileri ve Deutsche Bank Direktörü de uğurlamada yer almışlardır. İngiltere Sefiri Sir Nikola Okonor'un eşi Lady Okonor'u uğurlamak üzere istasyona giden Tercüman-1 Divan-1 Hümayun ve Teşrifat-1 Umumiye Nazırı Galib Paşa da Prens Georg'a resmî vedada bulunmuştur. Prens Georg, Hayreddin Beyefendi'den İstanbul'da bulundukları sürece kendilerine gösterilen alakadan dolayı teşekkürlerinin Sultan II. Abdülhamid'e arz edilmesini

60 "Prens Georg Hazretleri", Tercüman-ı Hakikat, nr: 9730, 2 Mayıs 1908, s. 1.

${ }^{61} \mathrm{Bu}$ arada bir süredir izinli olarak Viyana'da bulunan Pallavicini ise eşi ve sefaret kâtibi ile birlikte Şark Sürat Katarı'yla İstanbul'a dönmüştür. Sefiri karşılamak üzere Teşrifatı Hariciye Hayreddin Beyefendi Sirkeci istasyonuna gönderilmiştir. Sadrazam Tercümanı Ahmed Muhtar Beyefendi ile Hariciye Nezareti Tercümanı Sadettin Beyefendi de Sirkeci istasyonuna giderek Pallavicini'yi karşılamışlardır. Ayrıca Avusturya Sefareti Müsteşarı Otto ile sefaret ve konsolosluk memurları ile maiyet vapuru zabitanı da Pallavicini'yi karşılayanlar arasında yer almışlardır. Rumeli şimendifer direktörü, Avusturya postanesi direktörü ve memurları dahi karşılama sırasında bulunmuşlardır ("Marki Pallavicini Hazretleri", Tercüman-ı Hakikat, nr: 9731, 3 Mayıs 1908, s. 1-2).

62 "Prens Georg Hazretleri", Tercüman-ı Hakikat, nr: 9731, 3 Mayıs 1908, s. 2.

63 "Prens Georg Hazretleri", Tercüman-ı Hakikat, nr: 9732, 4 Mayıs 1908, s. 1. Prens Georg 3 Mayıs akşamı Avusturya Sefareti'ne giderek Viyana'dan dönen Büyükelçi Pallavicini'yi ziyaret etmiştir ("Prens Georg Hazretleri", Tercüman-ı Hakikat, nr: 9733, 5 Mayıs 1908, s. 1). 
rica ederek İstanbul seyahatini sona erdirmiştir. ${ }^{64}$ Prens Georg İstanbul'dan Viyana'ya geçmiş ve İmparator Franz Joseph ile görüştükten sonra buradan da Münih'e gitmiştir. ${ }^{65}$

\section{Sonuç}

Kadim şehirlerden biri olan İstanbul, pek çok hanedan üyesi tarafından ziyaret edilmiştir. İmparator Franz Joseph ve oğlu Veliaht Arşidük Rudolf’ten sonra kızı Prenses Gisela da oğulları ile birlikte İstanbul'un ağırladığı misafirler arasında yer almıştır.

Sultan II. Abdülhamid Prenses Gisela'yı Yıldız Sarayı'nda ağırlamayı teklif etmiştir. Ancak Prenses Gisela, İmparator Franz Joseph gibi dönemin Avrupai mekânlarından biri olarak anılan Pera Palas Oteli'nde kalmıştır. İstanbul içindeki ulaşımları kendilerine tahsis edilen Istabl-Âmire arabalarıyla sağlanmış, deniz yolu için kullandıkları ulaşım aracı ise istimbot olmuştur. Bu seyahat süresince Prenses Gisela'ya mihmandar tayin edilmiş ve Sultan II. Abdülhamid'in maiyetindeki çavuşlar da atlı olarak eşlik etmişlerdir.

Prenses Gisela ve beraberindekiler saray, cami, türbe, müze, kasır, hastane ve fabrika ziyaretleri gerçekleştirmiş̧lerdir. Roma, Bizans ve Osmanlı dönemine ait bazı eserler görmüşlerdir. Batı müziği eğitimi alan ve Batı müziğine ilgili duyan Sultan II. Abdülhamid tarafından Yıldız Sarayı'nda verilen ziyafette yemek sırasında müzik dinletisi icra edilmiş ve yemekten sonra tiyatro oyunu sergilenmiştir. Ayrıca modern anlamda ilk örnekleri Avrupa'da görülen kartvizitler ziyaret, iadeiziyaret ve veda zımnında kullanılmıştır. Bahsi geçenler Osmanlı Devleti'nin; devraldığı köklü mirasının, güç ve ihtişamının, gelişen sanayisinin ve Batı'ya dönük yüzünün yansıtılması için birer vesile teşkil etmişlerdir.

Öte yandan Prenses Gisela ve beraberindekiler, seyahatleri Paskalya'ya denk geldiğinden Santa Maria Kilisesi'nde icra edilen ruhani ayine katılmışlardır. Söz konusu Katolik Kilisesi ise girişinde yer alan kitabe nedeniyle ayrı bir önem arz etmektedir. 1904 tarihli bu kitabede Sultan II. Abdülhamid'e kilisenin yapımı esnasındaki yardımlarından dolayı bir teşekkür yazısı bulunmaktadır. Bu durum Prenses Gisela ve beraberindekiler için de dikkate ve takdire şayan bulunmuş olmalıdır. Keza Galata Mevlihanesi'nin ve Perşembe Tekkesi'nin ziyaret edilmiş olması da dikkat çeken bir diğer husustur. Bu durum ise Osmanlı kültürüne ve dinî değerlerine duydukları ilgi ya da merakla ilişkilendirilebilir.

Prenses Gisela'nın İstanbul seyahati Avusturya basınında da geniş yer bulmuştur. Avusturya gazeteleri Sultan II. Abdülhamid'in, bu vesile ile İmparator Franz Joseph'e dostluğunu göstermek istediğinden ve Prenses Gisela'yı onurlandırmak için oldukça çaba sarf ettiğinden bahsetmişlerdir. Bilhassa Prenses Gisela'ya verilen özel Mecidiye nişanını o zamana kadar oldukça az kişiye verildiği için dikkate değer görmüşlerdir.

Çalışmada elde edilen bulgulara göre Prenses Gisela İstanbul' da bulunduğu sürece Mevlid Alayı, Cuma selamlığı ve onurlarına düzenlenen gala yemeği dolayısıyla Sultan II. Abdülhamid ile üç kez yüz yüze görüşmüştür. Sultan, hatırlarını sormak için Pera Palas Oteli'ne memur göndermek suretiyle de misafirlere ilgisini eksik etmemiştir. Ayrıca Prenses Gisela, Prens Georg, Prens Konrad ve Prens Heinrich çeşitli Osmanlı nişanları ile taltif edilmiş, kendilerine hediyeler verilmiştir. Keza Avusturya Sefareti Maslahatgüzarı Otto'nun da bir nişanla taltif edildiği görülmektedir. Bu seyahatle ilgili olarak çalışmada Avusturya-Macaristan Büyükelçisi Pallavicini'nin isminin çok fazla zikredilmemiş olması ise Prenses Gisela'nın İstanbul'da olduğu dönemde Pallavicini'nin izinli olarak Viyana'da bulunmasından kaynaklanmıştır.

\footnotetext{
64 "Prens Georg Hazretleri", Tercüman-ı Hakikat, nr: 9733, 5 Mayıs 1908, s. 1.

65 “Aus hofkreisen", Wiener Salonblatt, nr: 20, 16 Mayıs 1908, s. 2.
} 
Sultan II. Abdülhamid'in İmparator Franz Joseph ile yaptığı yazışmalar ise ayrıca dikkate değerdir. Uvaç-Mitroviçe demir yolu projesinin yol açtığ 1 siyasi gelişmelerle yakınlaşan ilişkiler bu yazışmalardaki dostane ifadelerle de kendini göstermiştir. Nitekim bu çalışmayla; İstanbul seyahati sırasında Prenses Gisela ve oğullarının kimler tarafından, nasıl karşılandıklarına, nerede kaldıklarına, onurlarına nasıl etkinlikler düzenlendiğine, kendilerine kimlerin nasıl eşlik ettiğine, İstanbul'un hangi görülmeye değer mekânlarını ziyaret ettiklerine, bu sırada hangi ulaşım araçlarını kullandıklarına, nasıl ve kimler tarafından uğurlandıklarına ayrıntılı betimlemelerle ışı tutulurken bu vesile ile genellikle çatışma ve rekabetle anılan Osmanlı ve Habsburglar arasındaki dostane ilişkilere delalet eden ve Avusturya İmparatoru Franz Joseph'in ifadesiyle "unutulması mümkün olmayan" hatıralar da gün yüzüne çıkarılmıştır.

\section{Kaynakça}

\section{Arşiv Belgeleri}

BEO: $3288 / 246587$

DH.MKT: 1246/1, 1257/47

İ.HR: $412 / 2$

TFR.I.M: 20/1934

Y.EE: 63/51

Y.MTV: $310 / 23$

Y.E.E: $83 / 10$

Y.PRK.DH: 14/43

Y.PRK.NMH: 1/7, 10/66

Y.PRK.TKM: 51/20

\section{Süreli Yayınlar}

"Von fremden Höfen", Sport \&Salon, nr: 12, 21 Mart 1908.

“Aus hofkreisen”, Wiener Salonblatt, nr: 14, 4 Nisan 1908.

"Hofnachrichten”, Das Vaterland (Abendblatt), nr: 166, 9 Nisan 1908.

“Hof- und Personalnachrichten”, Neues Wiener Journal, nr: 5197, 9 Nisan 1908.

“Prinzessin Gisela von Bayern”, Deutsches Volksblatt, nr: 6923, 9 Nisan 1908.

“Orientreise der Prinzessin Gisela von Bayern”, Die Zeit (Abendblatt), nr: 1993, 10 Nisan 1908.

"Vom Hofe, Neuigkeits-Welt Blatt, nr: 84, 10 Nisan 1908.

“Hofnachrichten”, Das Vaterland (Morgenblatt), nr: 169, 11 Nisan 1908.

“Orientreise der Prinzessin Gisela von Bayern”, Neues Wiener Journal, nr: 5199, 11 Nisan 1908.

"Von fremden Höfen", Wiener Salonblatt, nr: 15, 11 Nisan 1908.

“Avusturya ve Macaristan Sefiri”, Tercüman-1 Hakikat, nr: 9710, 12 Nisan 1908.

"Prinzessin Gisela in Konstantinopel”, Die Zeit (Morgenblatt), nr: 1995, 12 Nisan 1908. 
"Prinzessin Gisela von Bayern in Konstantinopel”, Neues Wiener Journal, nr: 5200, 12 Nisan 1908.

"Prenses Jizel Hazretleri”, Tercüman-1 Hakikat, nr: 9710, 12 Nisan 1908.

“Türkei”, Wiener Zeitung, nr: 86, 12 Nisan 1908.

"Prinzessin Gisela in Konstantinopel”, Das Vaterland (Abendblatt), nr: 172, 13 Nisan 1908.

"Prinzessin Gisela in Konstantinopel”, Die Zeit (Abendblatt), nr: 1996, 13 Nisan 1908.

“Prenses Jizel Gizela Hazretleri”, Tercüman-1 Hakikat, nr: 9711, 13 Nisan 1908.

“Türkei”, Wiener Abendpost, nr: 86, 13 Nisan 1908.

"Prenses Jizel Gizela Hazretleri”, Tercüman-1 Hakikat, nr: 9712, 14 Nisan 1908.

"Prinzessin Gisela in Konstantinopel”, Das Vaterland (Morgenblatt), nr: 173, 14 Nisan 1908.

"Prinzessin Gisela von Bayern in Konstantinopel”, Neues Wiener Journal, nr: 5202, 14 Nisan 1908.

“Türkei”, Wiener Zeitung, nr: 87, 14 Nisan 1908.

“Prenses Gizela Hazretleri”, Tercüman-1 Hakikat, nr: 9713, 15 Nisan 1908.

"Prinzessin Gisela in Konstantinopel”, Das Vaterland (Morgenblatt), nr: 175, 15 Nisan 1908.

"Prinzessin Gisela in Konstantinopel”, Die Zeit (Morgenblatt), nr: 1998, 15 Nisan 1908.

“Türkei”, Wiener Zeitung, nr: 88, 15 Nisan 1908.

“Prenses Gizela Hazretleri”, Tercüman-1 Hakikat, nr: 9714, 16 Nisan 1908.

"Prinzessin Gisela in Konstantinopel”, Das Vaterland (Abendblatt), nr: 178, 16 Nisan 1908.

“Prinzessin Gisela in Konstantinopel”, Die Zeit (Abendblatt), nr: 1999, 16 Nisan 1908.

“Prenses Gizela Hazretleri”, Tercüman-1 Hakikat, nr: 9715, 17 Nisan 1908.

“Prenses Gizela Hazretleri”, Tercüman-1 Hakikat, nr: 9716, 18 Nisan 1908.

“Prinz Georg von Bayern”, Das Vaterland (Abendblatt), nr: 182, 18 Nisan 1908.

"Prenses Gizela Hazretleri”, Tercüman-1 Hakikat, nr: 9717, 19 Nisan 1908.

"Nişan”, Tercüman-1 Hakikat, nr: 9718, 20 Nisan 1908.

"Prenses Gizela Hazretleri”, Tercüman-1 Hakikat, nr: 9718, 20 Nisan 1908.

"Fehametlü Prens Henri Hazretleri”, Tercüman-1 Hakikat, nr: 9719, 21 Nisan 1908.

“Prenses Gizela Hazretleri”, Tercüman-1 Hakikat, nr: 9719, 21 Nisan 1908.

“Die Erkrankung der Prinzessin Gisela”, Die Zeit (Morgenblatt), nr: 2004, 22 Nisan 1908.

"Erkrankung der Prinzessin Gisela von Bayern in Konstantinopel”, Neues Wiener Journal, nr: 5209, 22 Nisan 1908.

“Prenses Gizela Hazretleri”, Tercüman-1 Hakikat, nr: 9720, 22 Nisan 1908.

"Prinzessin Gisela von Bayern in Konstantinopel", Das Vaterland (Morgenblatt), nr: 185, 22 Nisan 1908.

“Türkei”, Wiener Zeitung, nr: 93, 22 Nisan 1908.

“Fehametlü Prens Georg Hazretleri”, Tercüman-1 Hakikat, nr: 9721, 23 Nisan 1908. 
“Prenses Gizela Hazretleri”, Tercüman-1 Hakikat, nr: 9722, 24 Nisan 1908.

"Hofnachricht”, Wiener Abendpost, nr: 96, 25 Nisan 1908.

“Prenses Gizela Hazretleri”, Tercüman-1 Hakikat, nr: 9723, 25 Nisan 1908.

"Prinzessin Gisela in Konstantinopel”, Die Zeit (Morgenblatt), nr: 2007, 25 Nisan 1908.

“Türkei”, Wiener Abendpost, nr: 96, 25 Nisan 1908.

“Prenses Gizela Hazretleri”, Tercüman-1 Hakikat, nr: 9724, 26 Nisan 1908.

“Prenses Gizela Hazretleri”, Tercüman-1 Hakikat, nr: 9725, 27 Nisan 1908.

"Prinzessin Gisela von Bayern in Konstantinopel”, Das Vaterland (Abendblatt), nr: 194, 27 Nisan 1908.

"Prinzessin Gisela in Konstantinopel”, Neues Wiener Journal, nr: 5214, 27 Nisan 1908.

“Türkei”, Wiener Abendpost, nr: 97, 27 Nisan 1908.

“Abreise der Prinzessin Gisela von Konstantinopel”, Neues Wiener Journal, nr: 5215, 28 Nisan 1908.

“Hofnachrichten”, Das Vaterland (Morgenblatt), nr: 195, 28 Nisan 1908.

"Prinzessin Gisela in Konstantinopel”, Die Zeit (Morgenblatt), nr: 2010, 28 Nisan 1908.

“Hamidiye Etfal Hastahane-i Âlisini Ziyaret”, Tercüman-1 Hakikat, nr: 9727, 29 Nisan 1908.

"Hofnachrichten", Das Vaterland (Abendblatt), nr: 198, 29 Nisan 1908.

“Nişan”, Tercüman-1 Hakikat, nr: 9727, 29 Nisan 1908.

"Prens Georg Hazretleri”, Tercüman-1 Hakikat, nr: 9728, 30 Nisan 1908.

"Prens Georg Hazretleri”, Tercüman-1 Hakikat, nr: 9729, 1 Mayıs 1908.

“Prens Georg Hazretleri”, Tercüman-1 Hakikat, nr: 9730, 2 Mayıs 1908.

“Marki Pallavicini Hazretleri”, Tercüman-1 Hakikat, nr: 9731, 3 Mayıs 1908.

"Prens Georg Hazretleri”, Tercüman-1 Hakikat, nr: 9731, 3 Mayıs 1908.

“Prens Georg Hazretleri”, Tercüman-1 Hakikat, nr: 9732, 4 Mayıs 1908.

“Prens Georg Hazretleri”, Tercüman-1 Hakikat, nr: 9733, 5 Mayıs 1908.

"Prinzessin Gisela von Bayern in Konstantinopel”, Die Zeit (Morgenblatt), nr: 2017, 5 May1s 1908.

“Aus hofkreisen”, Wiener Salonblatt, nr: 19, 9 Mayıs 1908.

“Aus hofkreisen”, Wiener Salonblatt, nr: 20, 16 Mayıs 1908.

“Amtlicher Teil”, Wiener Zeitung, nr: 97, 26 Nisan 1913.

"Prinzessin Gisela", Reichspost, nr: 210, 29 Temmuz 1932.

“Prinzessin Gisela von Bayern”, Wiener Zeitung, nr: 174, 29 Temmuz 1932.

Diğer Araştırmalar

Bridge, F. R. “Habsburg Monarşisi ve Osmanlı İmparatorluğu, 1900-1918.” Osmanlı İmparatorluğu’nun Sonu ve Büyük Güçler, Marian Kent. İstanbul: Alfa Yayınları, 2013.

Buluş, Abdulkadir. "Osmanlı Tekstil Sanayi ve Hereke Halı Fabrikası." Doktora tezi, İstanbul Üniversitesi, 2000. 
Eyice, Semavi. “Ahmed III Çeşmesi”, TDV İslâm Ansiklopedisi, II (İstanbul 1989), ss. 38-39.

Gönenç, Senem. "Osmanl1-Avusturya Macaristan İmparatorluğu İlişkileri (1908-1914) ve Ders Kitaplarına Yansımaları.” Doktora tezi, İstanbul Üniversitesi, 2019.

Öztuna, Yılmaz. II. Abdülhamîd: Zamânı ve Şahsiyeti. İstanbul: Kubbealtı, 2008.

Tanman, M. Baha, Yılmaz, Hasan Kâmil. "Bandırmalızâde Tekkesi”, TDV İslâm Ansiklopedisi, V (İstanbul 1992), ss. 54-55. 


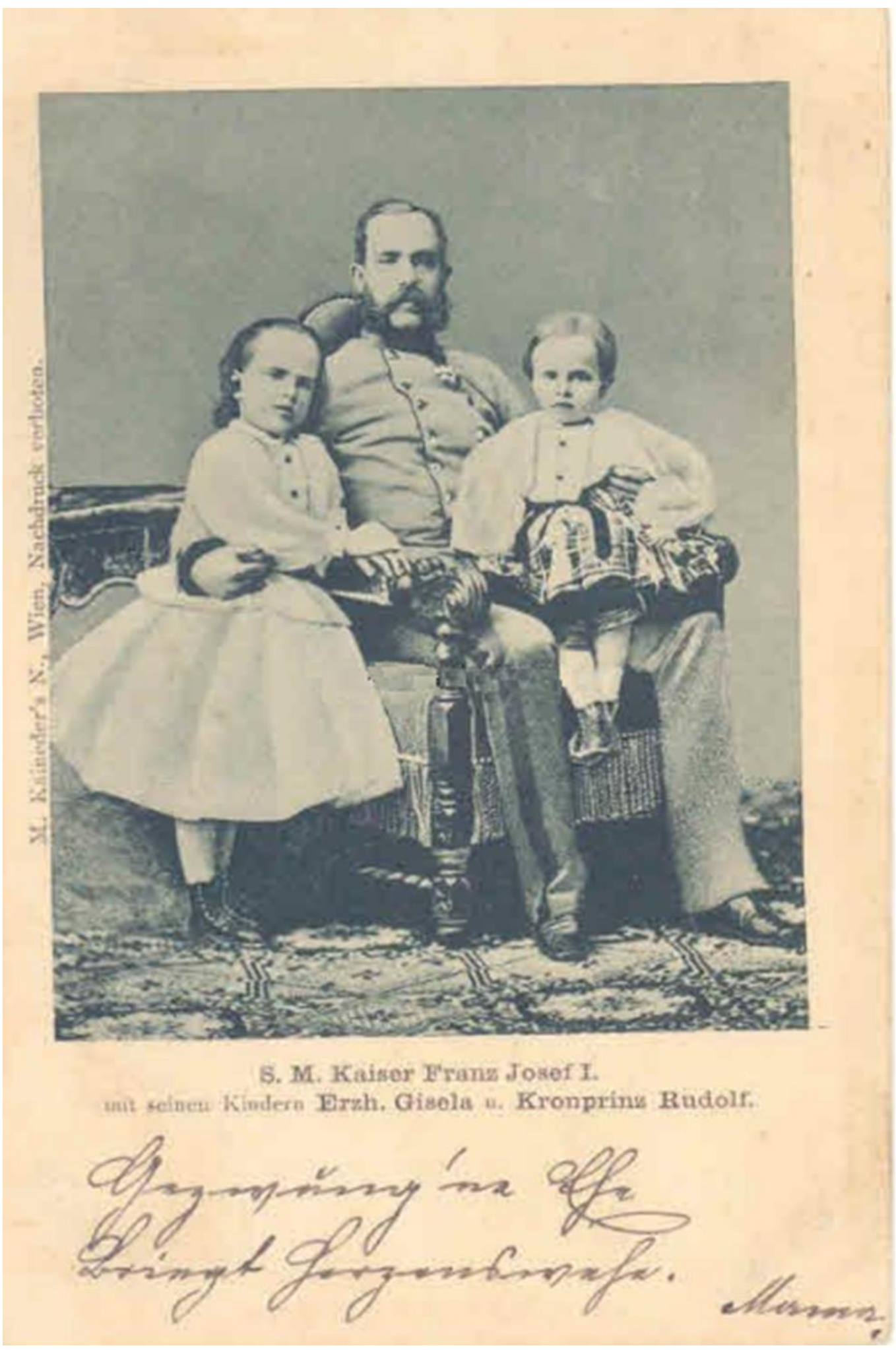

EK-1 Kayzer Franz Joseph çocukları Veliaht Prens Rudolf ve Arşidüşes Gisela ile birlikte (Kaiser Franz Joseph mit Kronprinz Rudolf und Erzherzogin Gisela, 1861, Österreichische Nationalbibliotek 


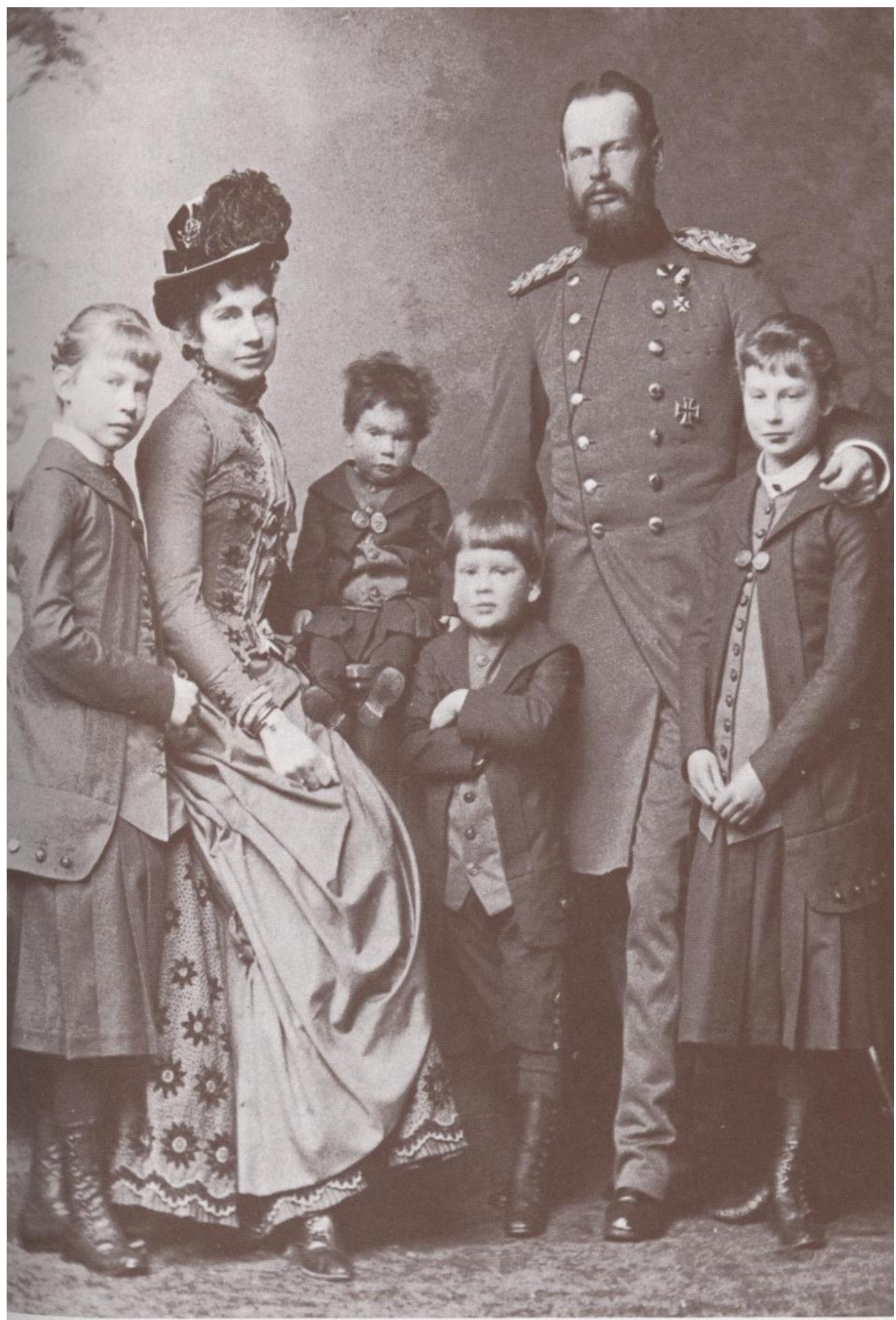

EK-2 Arşidüşes Gisela ve Bavyera Prensi Leopold, çocukları Elisabeth, Konrad, Georg ve Auguste ile birlikte (Erzherzogin Gisela und Prinz Leopold von Bayern: Mit ihren Kindern Elisabeth, Konrad, Georg und Auguste, 1885, Österreichische Nationalbibliotek) 


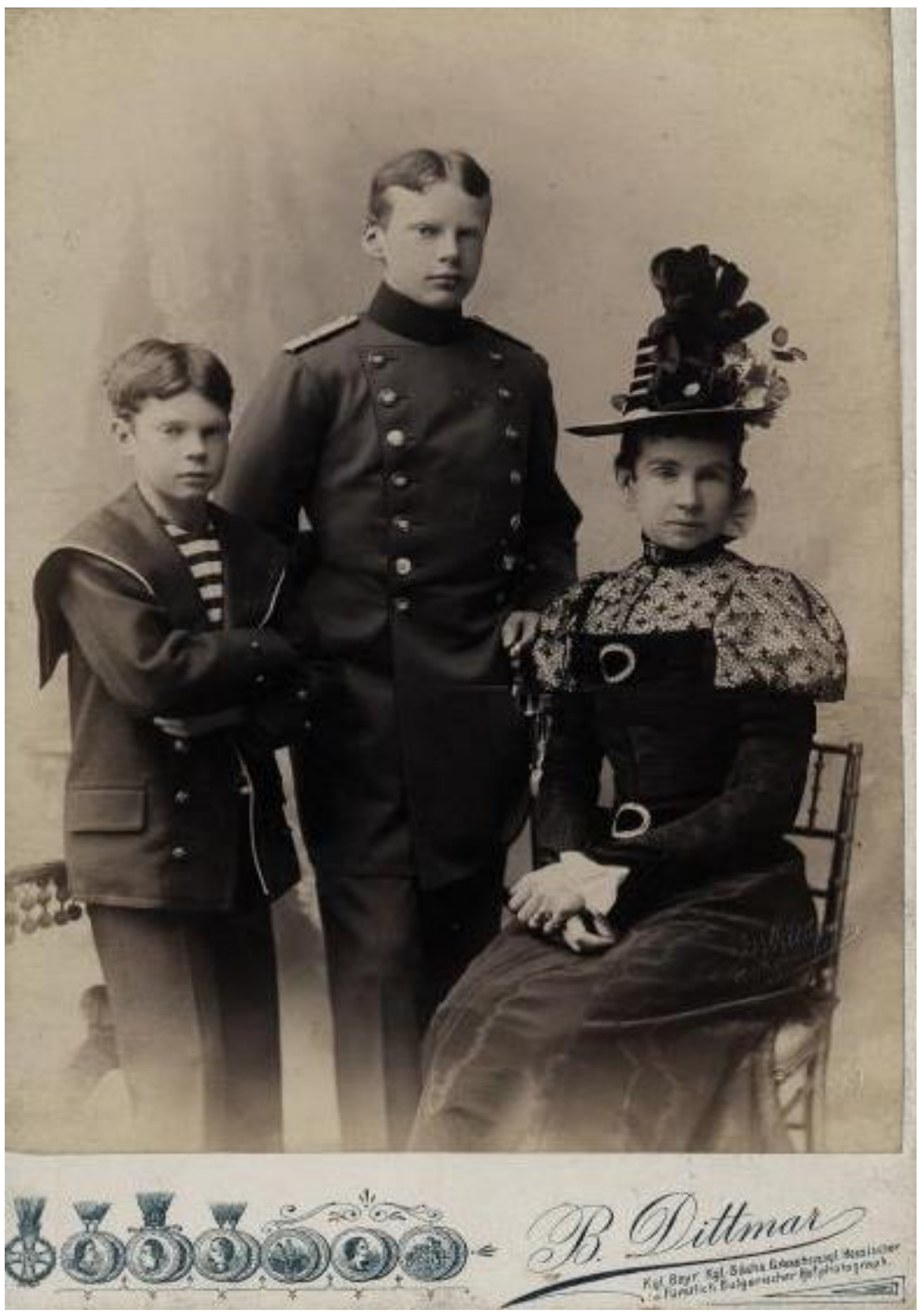

EK-3 Bavyera Prensesi Gisela, oğulları Georg Franz Joseph ve Konrad Luitpold Franz ile birlikte (Erzherzogin Gisela, verheiratete Prinzessin von Bayern, mit ihren Söhnen Georg Franz Joseph und Konrad Luitpold Franz, Österreichisches Staatsarchiv) 